\title{
Characteristics of la literatura: A Reference Study of Spanish and Latin American Literature
}

\author{
David S. Nolen
}

The goal of this study is to examine the characteristics of scholarly communication, with particular emphasis on the usage of the monograph, in the field of Spanish and Latin American literature over a 30-year period. In addition, this study examines the age of materials referenced in an effort to gain insight into the shelf-life of these materials. Although monographs and literary works predominated, the usage of volumes of collected essays showed significant increase. Monographs, collected essays, and journal articles published within the preceding 20-25 years were most referenced.

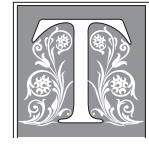

he current state of scholarly communication has become a continuing topic of dialog among librarians, scholarly publishing agents, and scholars, especially in the humanities. For the most part, these parties have agreed that the current model for scholarly communication must be examined and reevaluated, due to the increasing tensions within the current model. As Chodorow has observed, libraries and humanities scholars have much at stake. Library budgets for the purchase of monographs have continued to shrink as the cost of journals has risen. This has in turn impacted the ability of university presses and other scholarly publishers to effectively produce scholarly monographs, since libraries have traditionally been the primary consumers of such products. ${ }^{1}$ Charting a course of action requires examining the model of scholarly communication across various disciplines and understanding the differences and similarities in how that communication is achieved.

Scholarly communication can be defined as the formal and informal means through which scholars in academic fields share information with colleagues and receive information from them. ${ }^{2}$ For the purposes of this paper, the formal, published forms of scholarly communication will be emphasized. The bibliometric techniques of citation analysis and reference study lend themselves particularly well to the study of the written manifestations of scholarly communication. Although these terms are used largely as synonyms throughout the literature, the current study emphasizes the distinction put forth by Cullars between these two techniques. Cullars distinguished a reference study-where all the internal

David S. Nolen is Assistant Professor, Humanities Reference Librarian, in the Mitchell Memorial Library of Mississippi State University; e-mail:dnolen@library.msstate.edu. Special thanks to Dr. Louis Pitschmann, Dr. Jeff Luzius, and Brad Brazzeal for their helpful input at various stages in this project's development. CDavid S. Nolen 
references, both in-text and in footnotes or endnotes, are counted-from a citation analysis, which typically does not count each time a particular source is referenced. ${ }^{3}$

Bibliometric studies have already been rigorously applied to the sciences, yielding valuable information about the nature of scholarly communication in those disciplines. ${ }^{4}$ Herubel and Buchanan highlighted in 1994 both the controversy of bibliometrics applied to the humanities and the opportunities for inquiry into scholarly communication in the humanities that it provides. ${ }^{5}$ Although several recent studies have begun to shed light on the overall patterns within the humanities, much remains to be studied. Kellsey and Knievel, authors of two recent citation studies, have offered meaningful comparisons of certain disciplines within the humanities, but have also proclaimed that more studies of individual disciplines are needed to construct a more complete portrait of patterns of scholarly communication within the humanities. ${ }^{6}$

The current study intends to add to the body of information about the process of scholarly communication that exists for the humanities by focusing on the field of Spanish-language literature. The first question that it seeks to address is whether similar patterns of monographic usage are observed in this area of literary studies when compared to other studies of multiple disciplines within the humanities ${ }^{7}$ and by studies of literature. ${ }^{8}$ In addition, it examines the age of materials referenced in an effort to gain insight into the shelflife of these materials, as several studies have emphasized. ${ }^{9}$ This study intends to address these questions by examining the materials referenced in articles found in three well-known journals in the field across a 30-year time span.

\section{Literature Review}

Cullars addressed the characteristics of scholarly citation patterns in Italian and Spanish monographs in his 1990 reference study, finding that monographs and primary sources predominated. Citations to books comprised 73.5 percent of total citations. ${ }^{10}$ Cullars counted all references to a given source, so his data give greater weight to more heavily-used sources. His conclusions generally match up with what other researchers have found when examining citation and reference patterns in English literature.

Cullars' study of Italian and Spanish literary monographs provides the most direct comparison to the current study, but comparisons to the findings of other studies produce meaningful insights as well. Two significant studies by Kellsey and Knievel have recently examined the citation patterns for a number of humanities fields, including literature, creating a better overall picture of scholarly communication across the humanities disciplines. ${ }^{11}$ A number of studies have focused on English-language literature, providing a meaningful context with which to draw parallels. In addition, Cullars' study of French and German literary monographs creates another useful comparison with non-English literary scholarship. ${ }^{12}$

One key issue in relation to all of these studies has been the definition of one category of resources: books. A number of studies, such as those by Budd, Heinzkill, and Stern, generally used the terms "book" and "monograph" as synonyms, ${ }^{13}$ but did not include a clear definition of exactly what resources were counted in this category. Cullars, on the other hand, explicitly stated that he included volumes of collected essays in his category of books in two of his articles. ${ }^{14}$ Although not explicitly stated in his studies of French, German, Italian, and Spanish literature, the final tabulations of data show great similarities to the data from his earlier studies of English and foreign language literature. ${ }^{15}$ In similar fashion, Knievel and Kellsey included not only book chapters but also dissertations in their counts of books for their 2005 article. ${ }^{16}$ If one defines a monograph as a booklength study of a single subject intended for a scholarly audience, ${ }^{17}$ then the data 
that merge monographic works into the same category as other works that are in book format lead to a certain difficulty in interpreting and comparing the results of these studies to those found in other studies. For example, Frost made it clear that she excluded volumes of collected essays from her data, while Thompson counted collected essays in a separate category from other book-bound formats. ${ }^{18}$ This allows for greater clarity when interpreting the findings of these studies.

A second point that is important to keep in mind when examining the current body of literature is that each of these studies approached the inclusion of primary and secondary sources in a slightly different way. For example, Budd, Frost, Stern, and Thompson specifically identified whether or not a reference was to what could be considered a primary source, such as the literary work being studied, or to a secondary source, meaning a scholarly work or another literary work cited to support a conclusion or provide additional perspectives..$^{19}$ Cullars also used this distinction in his studies of French, German, Italian, and Spanish literature. $^{20}$

In addition, the way in which the various categories of resources were counted must also be addressed. Heinzkill clarified in his 1980 study that only references found in footnotes were counted and only the first citation to a work was counted, excluding subsequent references to the same work. ${ }^{21}$ Thompson also counted only the first citation to a given work. ${ }^{22}$ Cullars, on the other hand, counted each time a particular source was mentioned, either in a note or in an in-text citation in all four of his studies referenced above..$^{23}$ This difference in methodology is important to consider when comparing the findings from these studies, because the counts that only include the first reference may not accurately reflect the weight of importance of a particular resource. In spite of these differences in how references were counted, all of the studies of English-language and foreign-language literature found that books or monographs far outpaced any other resources used by scholars.

Age of sources cited has also been taken up by several of these studies. Cullars, Heinzkill, and Stern all emphasized the high proportions of materials cited that had been published within the preceding 30-40 years of the article being studied. ${ }^{24}$ While Budd and Thompson also found that the majority of references were to more recently published materials, they both concluded that the overall range of ages for citations was broad, ${ }^{25}$ leading Thompson to conclude that scholars in the humanities were more likely to utilize sources from "a broad age spectrum," which is to say that these scholars make use of newly published material alongside established, well-known materials. ${ }^{26}$

\section{Methodology}

In this study, the author selected three well-known journals of Spanish and Latin American literature as the objects of study. Revista Iberoamericana, Hispania, and Hispanic Review were selected for several reasons. First of all, the author was familiar with them from his previous graduate and undergraduate studies in Spanish Literature. These journals all have a long history of publication, more than adequately covering the years of the intended sample. In addition, these journals cover a wide topical range within Latin American literature (including both Spanish and Portuguese literature), Spanish Peninsular literature, and literary criticism. Finally, by performing a Cited Reference Search in the Arts and Humanities Citation Index through the ISI Web of Knowledge, the author found that these three journals returned the highest number of overall citations of the Spanishlanguage literary journals he compared using the ISI Web of Knowledge.

Although this process of selection resulted in the choice of only three journals in a nonrandomized sample to represent the entire field, it also limited the sample to the three most cited journals in this 
field, making it more manageable for study purposes. As stated generally by Nicholas and Ritchie, ${ }^{27}$ in this case selective sampling rather than random sampling may suffice because the group selected (the three most cited journals of Spanish-language literature) is the object of study. This select sample provides a snapshot of the sources used by arguably the most successful scholars in the field. Because of this reduction in the sample size, all articles that fit the criteria described below were used for the investigation.

For each of the three journals, the author of the current study examined the references contained in the literary studies section of the volumes from 1970 and 2000. Each journal primarily contains articles focusing on critical studies relating to works of literature, particular authors, or literary movements, or has a designated section for such articles. By limiting the study to articles contained in this section of each journal, only those articles that are annotated bibliographies or, as in the case of Hispania, academic articles relating to pedagogy or linguistic concerns and not literary studies, were excluded. The author has chosen this time span to allow for changes that may have occurred in reference patterns from one generation of scholars to another.

For this study, the methodology encompassed counting footnotes or endnotes (usually containing full citation data for a given source) and also in-text references, which typically reference a source previously cited in a footnote or endnote. Each reference to a source was counted so that the final numbers would reflect a higher weight for the items most utilized by the article author. As mentioned previously in Cullars' definition, ${ }^{28}$ this style of counting gives the current study more of the character of a study of the internal references. Although the nature of counting in-text or implicit citations is in many ways subjective, it also emphasizes the extent to which certain resources were used more frequently or less frequently within the article. As described above, many previous studies did not include subsequent references to a given resource in the overall counts.

The author began by categorizing the references into 18 different categories. The largest categories were scholarly monographs, journal articles, collected essays, and literary works. The remaining categories exhibited so few citations in any one category that they have been collapsed into one category termed "other items." This category of other items includes theses and dissertations, newspapers, and documents of an autobiographical nature, such as letters.

This article limits its definition of scholarly monographs to the definition utilized by Mendez and Chapman: book-length studies of a single subject intended for a scholarly audience. ${ }^{29}$ The category of collected essays therefore encompassed book-bound essay and article collections. The term "literary works" was used to designate the work being studied in each article, usually a work of literary fiction, along with any fictional works used as secondary sources. By grouping all literary works together, this study highlights the scholarly sources that are used as secondary sources, making the categorization of works into primary or secondary sources seen in other studies unnecessary. Publication dates were collected for scholarly monographs, journal articles, and other books. These data were then compiled in Microsoft Excel spreadsheets to tabulate percentages for the categories and facilitate comparison in formatted tables.

Table 1 represents the general profile of the data. For Hispania and Hispanic Review, the average references per article increased from 1970 to 2000, but so did the average length in pages per article. Revista Iberoamericana, however, exhibited a decrease in average references along with an increase in average pages per article. This decrease may be explained by the significant increase in the number of articles appearing in Revista Iberoamericana from 1970 to 2000. 


\begin{tabular}{|l|c|c|c|c|}
\hline \multicolumn{5}{|c|}{ TABLE 1 } \\
& Articles & References & $\begin{array}{c}\text { Average } \\
\text { References } \\
\text { per Article }\end{array}$ & $\begin{array}{c}\text { Average } \\
\text { Pages per } \\
\text { Article }\end{array}$ \\
\hline \hline & $(\#)$ & $(\#)$ & $(\#)$ & $(\#)$ \\
\hline Hispania 1970 & 25 & 2,152 & 86.08 & 7.63 \\
\hline Hispania 2000 & 20 & 1,829 & 91.45 & 10.34 \\
\hline Hispanic Review 1970 & 14 & 1,348 & 96.29 & 15.67 \\
\hline Hispanic Review 2000 & 16 & 1,593 & 99.56 & 17.88 \\
\hline Revista Iberoamericana 1970 & 24 & 1,816 & 75.67 & 14.95 \\
\hline Revista Iberoamericana 2000 & 41 & 2,873 & 70.07 & 15.29 \\
\hline
\end{tabular}

\section{Results and Discussion}

As is evident from table 2, literary works, used as either the object of study or as secondary sources, continue to make up the bulk of referenced sources. This corroborates what Cullars found in his study of Italian and Spanish monographs, with 57.5 percent of Spanish citations to literary texts. ${ }^{30}$ However, their overall number and percentage of total references has declined considerably from 1970 to 2000, dropping 19.5 percent. In the 1970 data, the average number of citations to literary works per article was 62.27 . The 2000 data showed a decrease to 45.36 citations per article, while the citations per article for scholarly monographs, journal articles, and collected essays all increased signifi- cantly. This decline, coupled with the increase in other categories, indicates a rise in the use of secondary scholarly sources.

As stated above, the data regarding secondary scholarly sources showed an increase in references to scholarly monographs, journal articles, and collected essays. However, while journal articles did increase somewhat in average number of citations per article and percentage of total references, the category of collected essays increased by a greater percentage, even surpassing the percentage of journal articles in the 2000 data. In addition, journal articles actually declined as a percentage of secondary sources, dropping from 23.42 percent in 1970 to 19.81 percent in the data from 2000. Collected essays also

\begin{tabular}{|l|c|c|c|c|c|c|}
\hline \multicolumn{7}{|c|}{$\begin{array}{c}\text { TABLE 2 } \\
\text { Journal Data }\end{array}$} \\
\hline \hline & \begin{tabular}{c} 
Data from the 3 journals, 1970 \\
Citations \\
\hline
\end{tabular} & $\begin{array}{c}\text { \% of } \\
\text { Total } \\
\text { Citations }\end{array}$ & $\begin{array}{c}\text { Average \# } \\
\text { Df Citations/ } \\
\text { Article }\end{array}$ & $\begin{array}{c}\text { \# of } \\
\text { Citations }\end{array}$ & $\begin{array}{c}\text { \% of } \\
\text { Total } \\
\text { Citations }\end{array}$ & $\begin{array}{c}\text { Average \# } \\
\text { of Citations/ } \\
\text { Article }\end{array}$ \\
\hline $\begin{array}{l}\text { Scholarly } \\
\text { monographs }\end{array}$ & 455 & $8.56 \%$ & 7.11 & 1,264 & $20.08 \%$ & 16.42 \\
\hline Journal articles & 311 & $5.85 \%$ & 4.86 & 555 & $8.82 \%$ & 7.21 \\
\hline Collected essays & 107 & $2.01 \%$ & 1.67 & 569 & $9.04 \%$ & 7.39 \\
\hline Literary works & 3,985 & $74.99 \%$ & 62.27 & 3,493 & $55.49 \%$ & 45.36 \\
\hline Other items & 456 & $8.58 \%$ & 7.13 & 414 & $6.58 \%$ & 5.38 \\
\hline & 5,314 & $100.00 \%$ & 83.03 & 6,295 & $100.00 \%$ & 81.75 \\
\hline
\end{tabular}


jumped from an average of 1.73 citations per article in the 1970 data to an average of 7.39 citations per article in 2000. These trends are particularly evident when data for secondary scholarly sources are compared, as seen in table 3 .

Table 3 gives a more precise picture of scholarly secondary sources used in these journals in 1970 and in 2000. By excluding literary works, examples of scholarly communication referenced in these articles can be more clearly seen. These results show sizable increases in the references to book sources (scholarly monographs and volumes of collected essays) while journals declined as a percentage of total secondary source references and usage of "other items" declined in raw number of references, percentage of the total, and average use per article. In particular, the significant increase in the use of collected essays from 1970 to 2000 merits further investigation in light of the larger questions about scholarly publishing trends.

When compared to previous studies, the current study found much lower percentages for monographic usage. Knievel and Kellsey, counting both book chapters and dissertations as books, found much higher numbers for monographic citations across the humanities, with an average of 74.3 percent of citations to monographs. They reported that 76.4 percent of citations in history and 83.0 percent of citations in literature were to monographs. ${ }^{31}$ Without distinguishing between monographs and other books, Heinzkill reported similarly high numbers for English-language literary journal citations in his studies, finding roughly 75 percent of citations were to books, ${ }^{32}$ while Stern found 82.7 percent of references were to books in her study of English literary scholarship. ${ }^{33}$ Thompson's study of nineteenth-century British and American literary studies acknowledged the distinction between books and what she termed book articles, finding that 67.6 percent of citations were to books, while 13.1 percent of citations were to book articles. However, like Heinzkill's 1980 study, Thompson counted only the first reference to a given work, so it is difficult to draw a close parallel with the data from the current study. ${ }^{34}$

The slight differences in methodologies likely result in these variations. For example, the exclusion of other literary works used as secondary sources may partially account for the apparently diminished percentage of monographic sources as compared to other studies. In addition, the separation of references to monographs and references to volumes of collected essays likely impacted the overall results of the current study. But there may be other factors at play as well. In the most directly comparable study, Cullars found 71.5 percent of Italian

\begin{tabular}{|c|c|c|c|c|c|c|}
\hline \multicolumn{7}{|c|}{$\begin{array}{c}\text { TABLE } 3 \\
\text { Secondary Sources }\end{array}$} \\
\hline & \multicolumn{3}{|c|}{1970 Data, Secondary Sources } & \multicolumn{3}{|c|}{2000 Data, Secondary Sources } \\
\hline & $\begin{array}{c}\text { \# of } \\
\text { Citations }\end{array}$ & $\begin{array}{c}\text { \% of } \\
\text { Total } \\
\text { Citations }\end{array}$ & $\begin{array}{c}\text { Average \# } \\
\text { of Citations/ } \\
\text { Article }\end{array}$ & $\begin{array}{c}\text { \# of } \\
\text { Citations }\end{array}$ & $\begin{array}{c}\% \text { of } \\
\text { Total } \\
\text { Citations }\end{array}$ & $\begin{array}{c}\text { Average \# } \\
\text { of Citations/ } \\
\text { Article }\end{array}$ \\
\hline $\begin{array}{l}\text { Scholarly } \\
\text { monographs }\end{array}$ & 455 & $34.26 \%$ & 7.22 & 1,264 & $45.11 \%$ & 16.42 \\
\hline Journal articles & 311 & $23.42 \%$ & 4.94 & 555 & $19.81 \%$ & 7.21 \\
\hline Collected essays & 107 & $8.21 \%$ & 1.73 & 569 & $20.31 \%$ & 7.39 \\
\hline \multirow[t]{2}{*}{ Other items } & 456 & $34.11 \%$ & 7.19 & 414 & $14.78 \%$ & 5.38 \\
\hline & 1,329 & $100.00 \%$ & 21.08 & 2,802 & $100.00 \%$ & 36.39 \\
\hline
\end{tabular}




\begin{tabular}{|l|c|c|c|c|c|c|}
\hline \multicolumn{7}{|c|}{ TABLE 4 } \\
\hline & $\begin{array}{l}\text { Cullars, } \\
\text { French }\end{array}$ & $\begin{array}{c}\text { Cullars, } \\
\text { German }\end{array}$ & $\begin{array}{c}\text { Cullars, } \\
\text { Italian }\end{array}$ & $\begin{array}{c}\text { Cullars, } \\
\text { Spanish }\end{array}$ & $\begin{array}{c}\text { Nolen, Spanish } \\
(1970 \text { data })\end{array}$ & $\begin{array}{c}\text { Nolen, Spanish } \\
\text { (2000 data) }\end{array}$ \\
\hline \hline $\begin{array}{l}\text { Book-format } \\
\text { secondary } \\
\text { sources }\end{array}$ & $33.7 \%$ & $47.2 \%$ & $43.2 \%$ & $42.5 \%$ & $42.5 \%$ & $65.4 \%$ \\
\hline
\end{tabular}

monographic citations and 75.5 percent of Spanish monographic citations were to books. However, he also divided the citations to books into primary and secondary sources. He reported that 45.2 percent of the Italian book references were to secondary sources, with only 42.5 percent of the Spanish book references to secondary sources. ${ }^{35} \mathrm{Simi}$ larly, he found 76.6 percent of German monographic citations and 80.7 percent of French monographic citations were to books. He again clarified that only 47.2 percent of those book citations were to secondary sources for German, while 33.7 percent of the French monographic citations were to books. ${ }^{36}$ These numbers more closely approximate the combined data for monographs and collected essays from the current study, particularly for the 1970 data. Since Cullars used a similar counting methodology, these results open the door for future research to address whether these use patterns are peculiar to Spanish and other foreign-language literary studies, or if the somewhat lower numbers are a result of this distinct methodology. The results of the current study also point to a significant increase in the use of book-format secondary sources in Spanish-language literary studies from 1970 to 2000, a trend that merits further study for other disciplines.

This study also examines the age of these secondary scholarly references. Literary works were excluded from the

\begin{tabular}{|l|c|c|l|c|c|}
\hline \multicolumn{5}{|c|}{ Monograph Ages, 1970 and 2000 Data } \\
\hline \hline \multicolumn{5}{|c|}{ Monograph Ages, 1970 Data } & \multicolumn{2}{c|}{ Monograph Ages, 2000 Data } \\
\hline & $\begin{array}{c}\text { \# of } \\
\text { Citations }\end{array}$ & $\begin{array}{c}\text { \% of Total } \\
\text { Citations to } \\
\text { Monographs }\end{array}$ & & $\begin{array}{c}\text { \# of } \\
\text { Citations }\end{array}$ & $\begin{array}{c}\text { \% of Total } \\
\text { Citations to } \\
\text { Monographs }\end{array}$ \\
\hline $1-5$ years & 67 & $15 \%$ & $1-5$ years & 199 & $16 \%$ \\
\hline $6-10$ years & 95 & $21 \%$ & $6-10$ years & 322 & $26 \%$ \\
\hline $11-15$ years & 59 & $13 \%$ & $11-15$ years & 172 & $14 \%$ \\
\hline $16-20$ years & 46 & $10 \%$ & $16-20$ years & 145 & $12 \%$ \\
\hline $21-25$ years & 45 & $10 \%$ & $21-25$ years & 103 & $8 \%$ \\
\hline $26-30$ years & 15 & $3 \%$ & $26-30$ years & 88 & $7 \%$ \\
\hline $31-35$ years & 11 & $2 \%$ & $31-35$ years & 61 & $5 \%$ \\
\hline $36-40$ years & 9 & $2 \%$ & $36-40$ years & 20 & $2 \%$ \\
\hline $41-45$ years & 23 & $5 \%$ & $41-45$ years & 32 & $3 \%$ \\
\hline $46-50$ years & 7 & $2 \%$ & $46-50$ years & 23 & $2 \%$ \\
\hline $50+$ years & 68 & $15 \%$ & $50+$ years & 78 & $6 \%$ \\
\hline & 445 & $100 \%$ & & 1243 & $100 \%$ \\
\hline
\end{tabular}




\begin{tabular}{|l|c|c|l|c|c|}
\hline \multicolumn{5}{|c|}{ Tournal Article Ages, 1970 and 2000 Data } \\
\hline \hline & $\begin{array}{c}\text { \# of } \\
\text { Citations }\end{array}$ & $\begin{array}{c}\text { \% of Total } \\
\text { Citations to } \\
\text { Journal Articles }\end{array}$ & & $\begin{array}{c}\text { J of } \\
\text { Citations }\end{array}$ & $\begin{array}{c}\text { Journal Article Ages, 2000 Data } \\
\text { Citations to } \\
\text { Journal Articles }\end{array}$ \\
\hline \hline 1-5 years & 134 & $45 \%$ & $1-5$ years & 118 & $22 \%$ \\
\hline $6-10$ years & 48 & $16 \%$ & $6-10$ years & 126 & $23 \%$ \\
\hline $11-15$ years & 25 & $8 \%$ & $11-15$ years & 74 & $14 \%$ \\
\hline $16-20$ years & 20 & $7 \%$ & $16-20$ years & 62 & $11 \%$ \\
\hline $21-25$ years & 4 & $1 \%$ & $21-25$ years & 39 & $7 \%$ \\
\hline $26-30$ years & 15 & $5 \%$ & $26-30$ years & 36 & $7 \%$ \\
\hline $31-35$ years & 10 & $3 \%$ & $31-35$ years & 18 & $3 \%$ \\
\hline $36-40$ years & 11 & $4 \%$ & $36-40$ years & 18 & $3 \%$ \\
\hline $41-45$ years & 4 & $1 \%$ & $41-45$ years & 6 & $1 \%$ \\
\hline $46-50$ years & 6 & $2 \%$ & $46-50$ years & 11 & $2 \%$ \\
\hline $50+$ years & 20 & $7 \%$ & $50+$ years & 40 & $7 \%$ \\
\hline & 297 & $100 \%$ & & 548 & $100 \%$ \\
\hline & & & & & \\
\hline
\end{tabular}

age data because the prevalence of various editions of literary texts, published in different years, would not provide an accurate picture of the age of secondary sources. The data represented in the following tables (tables 5, 6, and 7) show the raw numbers and percentages for each age category. As in the previous tables, the

TABLE 7

Ages of Other Books, 1970 and 2000 Data

\begin{tabular}{|l|c|c|l|c|c|}
\hline \hline \multicolumn{2}{|c|}{ Other Book Ages, 1970 Data } & \multicolumn{3}{c|}{ Other Book Ages, 2000 Data } \\
\hline Citations & $\begin{array}{c}\text { \% of Total } \\
\text { Citations to } \\
\text { Other Books }\end{array}$ & $\begin{array}{c}\text { \# of } \\
\text { Citations }\end{array}$ & $\begin{array}{c}\text { \% of Total } \\
\text { Citations to } \\
\text { Other Books }\end{array}$ \\
\hline $1-5$ years & 34 & $36 \%$ & $1-5$ years & 106 & $19 \%$ \\
\hline $6-10$ years & 8 & $8 \%$ & $6-10$ years & 152 & $28 \%$ \\
\hline $11-15$ years & 14 & $15 \%$ & $11-15$ years & 96 & $17 \%$ \\
\hline $16-20$ years & 8 & $8 \%$ & $16-20$ years & 66 & $12 \%$ \\
\hline $21-25$ years & 4 & $4 \%$ & $21-25$ years & 28 & $5 \%$ \\
\hline $26-30$ years & 6 & $6 \%$ & $26-30$ years & 8 & $1 \%$ \\
\hline $31-35$ years & 4 & $4 \%$ & $31-35$ years & 13 & $2 \%$ \\
\hline $36-40$ years & 0 & $0 \%$ & $36-40$ years & 9 & $2 \%$ \\
\hline $41-45$ years & 14 & $15 \%$ & $41-45$ years & 20 & $4 \%$ \\
\hline $46-50$ years & 0 & $0 \%$ & $46-50$ years & 4 & $1 \%$ \\
\hline $50+$ years & 3 & $3 \%$ & $50+$ years & 47 & $9 \%$ \\
\hline & 95 & $100 \%$ & & 549 & $100 \%$ \\
\hline
\end{tabular}


raw numbers represent the total number of references to works that fall into the given age range. Multiple references to single works were counted to accurately reflect the actual level of usage of a given item by an author.

Although a number of reference and citation studies have asserted that the humanities depend on a much larger portion of older materials than other disciplines, especially the sciences, these data demonstrate a much greater dependence on more recent material for secondary references to scholarly work. Cullars' data on Spanish literary monographs and Heinzkill's most recent citation study of English and American literary journals also indicate this preference for more recent materials. ${ }^{37}$ As demonstrated in the preceding tables, the bulk of references to scholarly monographs were to those monographs that had been published in the 25 years immediately preceding the publication of the source article -69 percent for the 1970 data, 76 percent for the 2000 data. In fact, the median age for monographs decreased from 16 years to less than 14 years from 1970 to 2000 . For both journal articles and volumes of collected essays, the greatest number of references was to items published in the previous 20 years. Although the median age for collected essays decreased only slightly from 13 years to 12 years, the median age for journal articles actually increased from roughly 8 to 13 years. These changes appear to indicate that newer monographs are being cited even more than in the past, while the shelf-life of journal articles may be increasing during the same period.

The decline in the median age of journal articles fits with the broader idea that older items were utilized to a greater degree in certain instances (see, for example, the data for journal articles older than 50 years, as well as the data for monographs older than 50 years from 1970). The author of this study found that many of these citations to older materials came from a single article and were not necessarily evenly distributed across all the journals. However, these data concur with Thompson's assertion that humanists use materials from a broad age range, rather than broadly using older materials. ${ }^{38}$

\section{Conclusions}

In terms of limitations, the use of journal article citation data for a humanities field where monographic sources are known to be the primary vehicle for scholarly communication may not accurately reflect scholar behavior on the whole. Additionally, items were counted as scholarly monographs or collected essays based on the citation given in the article and the context in which it was referenced. This could, unfortunately, lead to some mistaken identifications of monographs and other materials. In spite of these and other limitations, the data collected are useful in determining a number of conclusions regarding the nature of scholarly communication within this field.

These data indicate that the scholarly monograph continues to be vital to the research of scholars in the field of Spanish and Latin American literature, and its importance seems to have actually increased in recent years. Journal articles, on the other hand, do not seem to be utilized to the same degree as monographs, and the usage of recent journals (from the immediately preceding five years) actually decreased as a percentage from 1970 to 2000. References to essays or articles contained in collected volumes, however, have greatly increased during the same time frame. These data suggest that the overall importance of secondary sources has increased in the field of Spanish and Latin American literature, with particular importance being placed on secondary sources that are published in book format, such as monographs and collected volumes of essays. This finding reflects the trends shown in other studies that emphasize the importance of these book format sources in the humanities as a whole, and in literary studies in particular. 
These findings suggest several avenues for further study. The present study could be expanded by including data from other well-known journals within the field. An analysis of the publisher data could also be undertaken to determine the primary publication sources of both the scholarly monographs and the collected essays, a further indicator of potential pressures with implications for the future of the model of scholarly practice and communication within the field. Finally, monographic citation data could be gathered from exemplary monographs published in the field to provide a further clarification of the role of each of these materials in the process of scholarly communication.
The demonstrated continuing importance of monographs and collections of essays highlights the challenges that scholars, librarians, and scholarly publishers are facing in the current environment. Book sources continue to play a vital role in humanities scholarship, even as the traditional model of scholarly publication and communication faces economic pressures that must be addressed. As the parties involved in this process continue to work together to seek a viable solution, the integral nature of the book source in the scholarly communication of the humanities must remain at the forefront of the discussion.

\section{Notes}

1. Stanley Chodorow, "The Once and Future Monograph," in The Specialized Scholarly Monograph in Crisis, or, How Can I Get Tenure if You Won't Publish My Book?: Proceedings of a Conference Sponsored by American Council of Learned Societies, Association of American University Presses, [and] Association of Research Libraries, Washington, D.C. September 11-12, 1997, ed. Mary M. Case (Washington, D.C.: Association of Research Libraries, 1999), 11-17.

2. Scholarly Communication and Bibliometrics, ed. Christine Borgman (Newbury Park, Calif.: Sage Publications, 1990).

3. John Cullars, "Characteristics of the Monographic Literature of British and American Literary Studies," College \& Research Libraries 46, no. 1 (1985): 511-22; "Citation Characteristics of Italian and Spanish Literary Monographs," The Library Quarterly 60, no. 4 (1990): 337-56.

4. Jennifer Knievel and Charlene Kellsey, "Citation Analysis for Collection Development: A Comparative Study of Eight Humanities Fields," Library Quarterly 75, no. 2 (2005): 142-68.

5. Jean-Pierre Herubel and Anne Buchanan, "Citation Studies in the Humanities and Social Sciences: A Selective and Annotated Bibliography," Collection Management 18, no. 3/4 (1994): 89-137.

6. Charlene Kellsey and Jennifer Knievel, "Global English in the Humanities? A Longitudinal Citation Study of Foreign-Language Use by Humanities Scholars," College E Research Libraries 65, no. 3 (2004): 194-204; Knievel and Kellsey, "Citation Analysis."

7. Knievel and Kellsey, "Citation Analysis"; Kellsey and Knievel, "Global English."

8. John Budd, "Characteristics of Written Scholarship in American Literature: A Citation Study," Library \& Information Science Research 8, no. 2 (1986): 189-211; Cullars, "British and American Literary Studies"; John Cullars, "Characteristics of the Monographic Scholarship of Foreign Literary Studies by Native Speakers of English," College and Research Libraries 49, no. 2 (1988): 157-70; John Cullars, "Citation Characteristics of French and German Literary Monographs," Library Quarterly 59, no. 4 (1989): 305-25; Carolyn O. Frost, "Use of Citations in Literary Research," Library Quarterly 49, no. 4 (1979): 399-414; Richard Heinzkill, "Characteristics of References in Selected Scholarly English Literary Journals," Library Quarterly 50, no. 3 (1980): 352-65; Richard Heinzkill, "References in Scholarly English and American Literary Journals Thirty Years Later: A Citation Study," College and Research Libraries 68, no. 2 (2007): 141-53; Madeleine Stern, "Characteristics of the Literature of Literary Scholarship," College \& Research Libraries 44, no. 4 (1983): 199-209; Jennifer W. Thompson, "The Death of the Scholarly Monograph in the Humanities? Citation Patterns in Literary Scholarship," Libri 52, no. 3 (2002): 121-36.

9. Budd, "Characteristics of Written Scholarship"; Cullars, "British and American Literary Studies," "Foreign Literary Studies"; Heinzkill, "English Literary Journals," "Thirty Years Later"; Stern, "Characteristics of the Literature"; Thompson, "Death of the Scholarly Monograph."

10. Cullars, "Italian and Spanish Literary Monographs."

11. Knievel and Kellsey, "Citation Analysis"; Kellsey and Knievel, "Global English."

12. Cullars, "French and German Literary Monographs." 
13. Budd, "Characteristics of Written Scholarship"; Heinzkill, "English Literary Journals," "Thirty Years Later"; Stern, "Characteristics of the Literature."

14. Cullars, "British and American Literary Studies," "Foreign Literary Studies."

15. Cullars, "French and German Literary Monographs," "Italian and Spanish Literary Monographs."

16. Knievel and Kellsey, "Citation Analysis."

17. Chodorow, "The Once and Future Monograph," 11-12; Meiyolet Mendez and Karen Chapman, "The Use of Scholarly Monographs in the Journal Literature of Latin American History," The Electronic Journal of Academic and Special Librarianship 7, no. 3 (2006), available online at http:// southernlibrarianship.icaap.org/content/v07n03/mendez_m01.htm [Accessed 16 January 2007]; Joan Reitz, "Monograph," Online Dictionary for Library and Information Science, available online at http://lu.com/odlis [Accessed 21 November 2008].

18. Frost, "Use of Citations"; Thompson, "Death of the Scholarly Monograph."

19. Budd, "Characteristics of Written Scholarship"; Frost, "Use of Citations"; Stern, "Characteristics of the Literature"; Thompson, "Death of the Scholarly Monograph."

20. Cullars, "French and German Literary Monographs," "Italian and Spanish Literary Monographs."

21. Heinzkill, “English Literary Journals," 354.

22. Thompson, "Death of the Scholarly Monograph," 127.

23. Cullars, "British and American Literary Studies," "Foreign Literary Studies," "French and German Literary Monographs," "Italian and Spanish Literary Monographs."

24. Cullars, "British and American Literary Studies," "French and German Literary Monographs," "Foreign Literary Studies," "Italian and Spanish Literary Monographs"; Heinzkill, "English Literary Journals," "Thirty Years Later"; Stern, "Characteristics of the Literature."

25. Budd, "Characteristics of Written Scholarship"; Thompson, "Death of the Scholarly Monograph."

26. Thompson, "Death of the Scholarly Monograph," 128-31.

27. David Nicholas and Maureen Ritchie, Literature and Bibliometrics (London: Clive Bingley, 1978).

28. Cullars, "British and American Literary Studies," "Italian and Spanish Literary Monographs."

29. Mendez and Chapman, "Journal Literature of Latin American History."

30. Cullars, "Italian and Spanish Literary Monographs," 344.

31. Knievel and Kellsey, "Citation Analysis," 146, 149.

32. Heinzkill, "English Literary Journals," 355; "Thirty Years Later," 142.

33. Stern, "Characteristics of the Literature," 203.

34. Heinzkill, "English Literary Journals," 354; Thompson, "Death of the Scholarly Monograph," $127-28$.

35. Cullars, "Italian and Spanish Literary Monographs," 344-45.

36. Cullars, "French and German Literary Monographs," 313, 316.

37. Cullars, "Italian and Spanish Literary Monographs"; Heinzkill, "Thirty Years Later."

38. Thompson, "Death of the Scholarly Monograph," 130. 